\title{
Correlation between mixed venous blood saturation and cardiac output in patients undergoing cardiac surgery procedures
}

\author{
Bartosz Szurlej ${ }^{1}$, Magda Piekarska ${ }^{2}$, Dariusz Szurlej ${ }^{3}$, Andrzej Węglarzy ${ }^{3}$, Tomasz Latusek ${ }^{1}$, \\ Ryszard Bachowski ${ }^{4}$
}

${ }^{1}$ student of Medical University of Silesia, Katowice

${ }^{2}$ graduate of Medical University of Silesia, Katowice

${ }^{3}$ Clinical Department of Cardiac Anesthesia and Postoperative Intensive Care, Upper Silesian Medical Centre SPSK No 7, Katowice

${ }^{4} 2^{\text {nd }}$ Chair and Department of Cardiac Surgery, Medical University of Silesia, Katowice

Kardiochirurgia i Torakochirurgia Polska 2013; 10 (1): 79-83

\begin{abstract}
Background: The physiological reaction to a decrease of cardiac output (CO) is an increase of oxygen extraction. Patients with compromised circulation often are not capable of this reaction. The oxygen concentration in such cases will not change with respect to the $\mathrm{CO}$; therefore the mixed venous blood saturation $\left(\mathrm{SvO}_{2}\right)$ will not be a reliable indicator of the blood flow. Aim of the study: The aim of the study was to determine the reliability of the correlation between hemodynamic parameters and indices of tissue oxygenation in patients undergoing cardiac surgery procedures.

Material and methods: We performed a retrospective analysis in 19 patients who required Swan-Ganz catheter (SGC) insertion. Measurements were taken at three time points. Values of cardiac index $(\mathrm{Cl})$, mixed venous oxygen saturation $\left(\mathrm{SvO}_{2}\right)$, oxygen uptake $\left(\mathrm{VO}_{2}\right)$, oxygen extraction ratio $\left(\mathrm{O}_{2} \mathrm{ER}\right)$, and base excess (BE) were analyzed and compared with oxygen partial pressure $\left(\mathrm{PaO}_{2}\right)$, carbon dioxide partial pressure $\left(\mathrm{PaCO}_{2}\right)$ and arterial blood saturation $\left(\mathrm{SaO}_{2}\right)$.

Results: Our study revealed an increase of $\mathrm{Cl}, \mathrm{VO}_{2}$ and $\mathrm{O}_{2} \mathrm{ER}$ and a decrease of $\mathrm{SvO}_{2}$ after the operation in comparison with the preoperative period. There was a positive correlation between the trends of $\mathrm{SvO}_{2}$ and $\mathrm{Cl}$ before and after the surgery. Conclusions: Correct values of $\mathrm{SaO}_{2}, \mathrm{PaO}_{2}$ and $\mathrm{PaCO}_{2}$ do not mean that the level of subcellular processes associated with the extraction of oxygen proceed in a physiological way. Only $\mathrm{SvO}_{2}$ and $\mathrm{Cl}$ results obtained with the $\mathrm{SGC}$ make it possible to assess the delivery of oxygen and its consumption at the tissue level.
\end{abstract}

Key words: Swan-Ganz catheter, cardiac surgery procedure, thermodilution.

\section{Streszczenie}

Wstęp: Fizjologiczną reakcją organizmu na obniżenie rzutu serca (cardiac output - CO) jest wzrost ekstrakcji tlenu. Pacjenci, u których występuje zaburzenie krążenia, często nie są zdolni do takiej reakcji. W takich przypadkach stężenie tlenu we krwi nie ulegnie zmianie w stosunku do CO i tym samym saturacja krwi żylnej mieszanej (mixed venous oxygen saturation - $\mathrm{SvO}_{2}$ ) nie będzie wiarygodnym wskaźnikiem przepływu krwi.

Cel pracy: Ocena miarodajności korelacji między parametrami hemodynamicznymi a wskaźnikami utlenowania tkankowego u pacjentów poddawanych zabiegom kardiochirurgicznym.

Materiat i metody: Badanie miało charakter retrospektywny. Ocenie poddano 19 pacjentów, którzy wymagali zastosowania cewnika Swana-Ganza (S-G). Pomiary wykonano w trzech punktach czasowych. Analizie poddano wartości wskaźnika sercowego (cardiac index $-\mathrm{Cl}$ ), $\mathrm{SvO}_{2}$, zużycia tlenu (oxygen uptake $-\mathrm{VO}_{2}$ ), wspótczynnika ekstrakcji tlenu (oxygen extraction ratio $-\mathrm{O}_{2} \mathrm{ER}$ ) i niedoboru zasad (base excess - BE). Uzyskane wartości porównywano z ciśnieniem parcjalnym tlenu we krwi tętniczej (partial pressure of arterial oxygen - $\mathrm{PaO}_{2}$ ), ciśnieniem parcjalnym dwutlenku węgla we krwi (partial pressure of carbon dioxide - $\mathrm{PCO}_{2}$ ), saturacją krwi tętniczej tlenem (arterial oxygen saturation $-\mathrm{SaO}_{2}$ ). Wyniki: Badanie wykazało wzrost $\mathrm{Cl}, \mathrm{VO}_{2}, \mathrm{O}_{2}$ ER oraz spadek $\mathrm{SvO}_{2}$ po zabiegu chirurgicznym w porównaniu z wartościami występującymi przed zabiegiem. Stwierdzono istnienie dodatniej korelacji między wartościami $\mathrm{SvO}_{2}$ i $\mathrm{Cl}$ przed zabiegiem i po operacji.

Wnioski: Prawidłowe wartości $\mathrm{SaO}_{2}, \mathrm{PaO}_{2}, \mathrm{PaCO}_{2}$ nie oznaczają, że ekstrakcja tlenu na poziomie subkomórkowym przebiega w sposób fizjologiczny. Jedynie wartości $\mathrm{SvO}_{2}$ i $\mathrm{Cl}$ uzyskane za pomocą cewnika S-G dają możliwość oceny dostarczania tlenu oraz jego zużycia przez tkanki.

Słowa kluczowe: cewnik Swana-Ganza, operacja kardiochirurgiczna, termodylucja. 


\section{Introduction}

Cardiac surgery with cardiopulmonary bypass (CPB) is a source of stress reaction and burdens the organism. Also the surgical wounds lead to permanent adrenergic stimulation and pain which requires the use of strong analgesics. The blood supply of the organs begins to be dependent on the CPB and short episodes of blood pressure drops affect the incidence of periods of temporary ischemia in organs. Removing the blood from the operation field by suction leads to erythrocyte damage. Cardiopulmonary bypass is also associated with the risk of organ micro- and macroembolization.

The activation of coagulation (the intrinsic and the extrinsic coagulation pathway), and the fibrinolysis process are the causes of consumptive coagulopathy. Coagulation failure is intensified by heparin. The manifestation of all of the physiological aberrations in the function of the organism is the occurrence of systemic inflammatory response syndrome (SIRS) in every patient after cardiac surgery with the use of CPB [1].

Evaluation of blood oxygen status in patients during cardiac surgery procedures is routinely carried out by oxygen partial pressure $\left(\mathrm{PaO}_{2}\right)$, carbon dioxide partial pressure $\left(\mathrm{PaCO}_{2}\right)$ and arterial blood saturation $\left(\mathrm{SaO}_{2}\right)$. These parameters allow an intermediate assessment of the oxygen delivery. If there were indications for Swan-Ganz catheter (SGC) insertion, it was used during the cardiac surgery operation to monitor the hemodynamic and the gas exchange parameters [2-4]. Initially, we get ten parameters which describe the cardiovascular system efficiency and four parameters of the systemic oxygen transport: mixed venous oxygen saturation $\left(\mathrm{SvO}_{2}\right)$, dissolved oxygen $\left(\mathrm{DO}_{2}\right)$, oxygen uptake $\left(\mathrm{VO}_{2}\right)$ and oxygen extraction ratio $\left(\mathrm{O}_{2} \mathrm{ER}\right)$.

Some of the hemodynamic parameters should be shown as an index value, that means calculated per $1 \mathrm{~m}^{2}$ of the body surface area (BSA). In the case of cardiac output (CO) it is the cardiac index $(\mathrm{Cl})$ [5]. By the use of the SGC it is also possible to take samples of the venous blood from the right atrium and samples of the mixed venous blood from the pulmonary artery. Some types of SGC give the ability of continuous monitoring of $\mathrm{SvO}_{2}$. The value of $\mathrm{SvO}_{2}$ shows both the oxygen delivery and the oxygen consumption. This value is dependent on the hemoglobin concentration $\left(\mathrm{C}_{\mathrm{Hb}}\right)$, arterial blood saturation and $\mathrm{CO}$ [5]. A proper compensation reaction of the decrease of $\mathrm{CO}$ is the increase of oxygen extraction $\left(\mathrm{O}_{2}\right.$ ER) from the capillary vessels, which is necessary to keep a constant value of the oxygen uptake $\left(\mathrm{VO}_{2}\right)$. Oxygen extraction adjustment, depending on the requirement, is especially intensified in life-threatening states; thus decrease of $\mathrm{SvO}_{2}$ may indicate a decrease of CO. Not every patient reacts with an increase of $\mathrm{O}_{2}$ ER to a decrease of blood flow. Often severely ill patients are not capable of such an adaptive reaction $[6,7]$. In these patients oxygen concentration will not change due to the changes in $\mathrm{CO}$; thus the value of $\mathrm{SvO}_{2}$ will not be a reliable indicator of the blood flow [6].

\section{Aim of the study}

The aim of the study was to determine the reliability of the correlation between hemodynamic parameters and in- dices of tissue oxygenation in patients undergoing cardiac surgery procedures and to assess the correlation between $\mathrm{SvO}_{2}$ and $\mathrm{Cl}$ in the study group.

\section{Material and methods}

A retrospective analysis was performed for 19 patients undergoing cardiac surgery procedures at the $2^{\text {nd }}$ Department of Cardiac Surgery, Medical University of Silesia in Katowice between February 2010 and April 2010. The study inclusion criterion was the requirement for hemodynamic and systemic oxygen transport monitoring by the use of the SGC. The study group is shown in Table I.

In all patients surgical anesthesia was performed by the same method of analgesic anesthesia by using etomidate, fentanyl and pancuronium. Anesthesia was maintained by using isoflurane and during CPB by continuous infusion of propofol and fentanyl.

Dopamine, adrenaline and noradrenaline were used for inotropic support as a monotherapy or in different combinations depending on the circulatory system condition. Values of $\mathrm{Cl}, \mathrm{SvO}_{2}, \mathrm{SaO}_{2}$ and $\mathrm{BE}_{\text {ecf }}$ (base excess in extracellular fluid) were analyzed.

Measurements by the SGC were taken in every patient at three time points: $\mathrm{T}_{0}$ - after the intubation and after the insertion of the $\mathrm{SGC} ; \mathrm{T}_{1}-15$ minutes after discontinuing CPB; and $T_{2}-30$ minutes after admitting the patient to the postoperative unit.

Obtained values were compared with the parameters used for the assessment of intermediate oxygen delivery: $\mathrm{PaO}_{2}$, $\mathrm{PaCO}_{2}, \mathrm{SaO}_{2}$ and $\mathrm{C}_{\mathrm{Hb}}$. $\mathrm{DO}_{2}, \mathrm{VO}_{2}$ and $\mathrm{O}_{2} \mathrm{ER}$ were also analyzed.

\section{Results}

Statistical analysis was performed using Statistica $P L$ v.5.0. Data from time points $T_{0}$ and $T_{2}$ were analyzed. The analysis did not contain data from time point $T_{1}$ because of the large range of obtained values.

Tab. I. Demographic data and types of cardiac surgery procedure characteristics

\begin{tabular}{lc} 
Data & Values \\
Number of patients $(n)$ & 19 \\
\hline Age & $62 \pm 12$ \\
\hline Sex $(\mathrm{M} / \mathrm{F})$ & $12 / 7$ \\
\hline BMI $\left(\mathrm{m}^{2} / \mathrm{kg}\right)$ & $28.02 \pm 2.8$ \\
\hline BSA $\left(\mathrm{m}^{2}\right)$ & $1.9 \pm 0.2$ \\
\hline CPB time (min) & $74 \pm 30$ \\
\hline Cross-clamp time (min) & $46 \pm 28$ \\
\hline Types of cardiac surgery procedures $(n)$ & 10 \\
CABG & 4 \\
AVR + MVR & 2 \\
MVR + CABG & 1 \\
AVR + CABG & 1 \\
AVR & 1 \\
aortic wrapping & \\
\hline BMI &
\end{tabular}

BMI - body mass index; BSA - body surface area; CPB - cardio-pulmonary bypass; CABG - coronary artery bypass graft; AVR - aortic valve replacement; MVR - mitral valve replacement 
Increase of the average value of $\mathrm{Cl}$ after the operation (Fig. 1) in comparison with the value before the operation $(p<0.05)$ was observed.

In the study group there was a decrease of $\mathrm{SvO}_{2}$ after the operation (Fig. 2) in comparison with the preoperative period $(p<0.05)$.

In two patients at time point $\mathrm{T}_{0}$ high values of $\mathrm{SvO}_{2}$ were noted: $95 \%$ and $96 \%$.

There was a positive correlation between the trends of $\mathrm{SvO}_{2}$ and $\mathrm{Cl}$ in patients before and after the surgery. The correlation coefficient $(r)$ before the operation (Fig. 3) was 0.38 $(p>0.05)$ and after the operation (Fig. 4 ) it was $0.52(p<0.05)$.

The $\mathrm{Cl}$ increased in $63 \%$ of patients, it decreased in $16 \%$, while in $21 \%$ of patients it did not change. Correct values of $\mathrm{Cl}$ in the study group before the operation were noted in $31 \%$ of patients and in $69 \%$ of patients this value was below the lower reference limit (reference limits: $2.4-4.0 \mathrm{l} / \mathrm{min} / \mathrm{m}^{2}$ ). After the operation $\mathrm{Cl}$ within the correct reference limits was noted in $42 \%$ of patients.

The $\mathrm{VO}_{2}$ after the operation increased in $84 \%$ of patients, a decrease was noted in $11 \%$, and in $5 \%$ of patients this value did not change $(p<0.05)$. In $15 \%$ of patients before the operation values of $\mathrm{VO}_{2}$ were noted within the reference limits (reference limits: $110-160 \mathrm{ml} / \mathrm{min} \times \mathrm{m}^{2}$ ). In $85 \%$ of patients the value of $\mathrm{VO}_{2}$ was below the lower reference limit while after the cardiac surgery procedure values within the reference limits were noted in $31 \%$ of patients. Values below the lower reference limit were noted in $69 \%$ of patients.

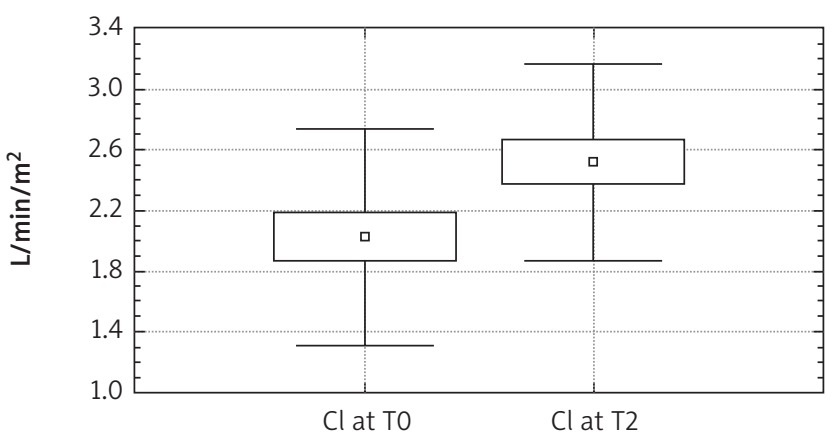

$$
\text { 工 } \pm \text { SD } \square \pm \text { SE } \quad \text { Mean }
$$

Fig. 1. Mean values of $\mathrm{Cl}$ before and after the operation $(p<0.02)$

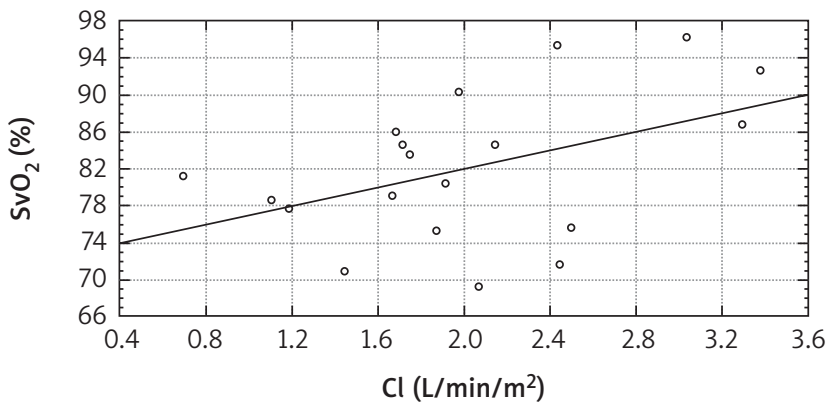

Fig. 3. Correlation between $\mathrm{Cl}$ and $\mathrm{SvO}_{2}$ before and after the operation $(r=0.38, p<0.10)$
An increase of $\mathrm{DO}_{2}$ took place in $58 \%$ of patients, a decrease in $37 \%$, and in $5 \%$ of patients this value did not change. Before the operation in $90 \%$ of patients values below the lower reference limit (reference limits: $520-570 \mathrm{ml} / \mathrm{min} \times \mathrm{m}^{2}$ ) were noted. None of the patients had a $\mathrm{DO}_{2}$ within the reference limits after the operation.

The $\mathrm{O}_{2} \mathrm{ER}$ was within the reference limits (reference limits: $20-30 \%$ ) in $53 \%$ of patients. An increase of $\mathrm{O}_{2}$ ER was noted in $84 \%$ of patients. After the cardiac surgery procedure an increase of $\mathrm{O}_{2} \mathrm{ER}$ above the upper reference limit was noted in $58 \%$ of patients. In $5 \%$ of patients the value of $\mathrm{O}_{2}$ ER was below the lower reference limit. Values within the reference limits were noted in $27 \%$ of patients.

The $\mathrm{BE}_{\text {ecf }}$ before the operation was below the lower reference limit in $10 \%$ of patients and above the upper reference limit in $5 \%$ of patients. After the operation $\mathrm{BE}_{\text {ecf }}$ was below the lower reference limit in $53 \%$ of patients and above the upper reference limit in $5 \%$ of patients.

In $50 \%$ of patients the postoperative course was complicated with atrial fibrillation $(n=4)$, increased postoperative drainage $(n=2)$, thrombocytopenia $(n=2)$, infection of the upper respiratory tract $(n=2)$ and urinary infection $(n=1)$. There was one death in the study group.

\section{Discussion}

The mean value of cardiac index $(\mathrm{Cl})$ after cardiac surgery using cardiopulmonary bypass was increased compared with the value before the operation, which leads to a posi-

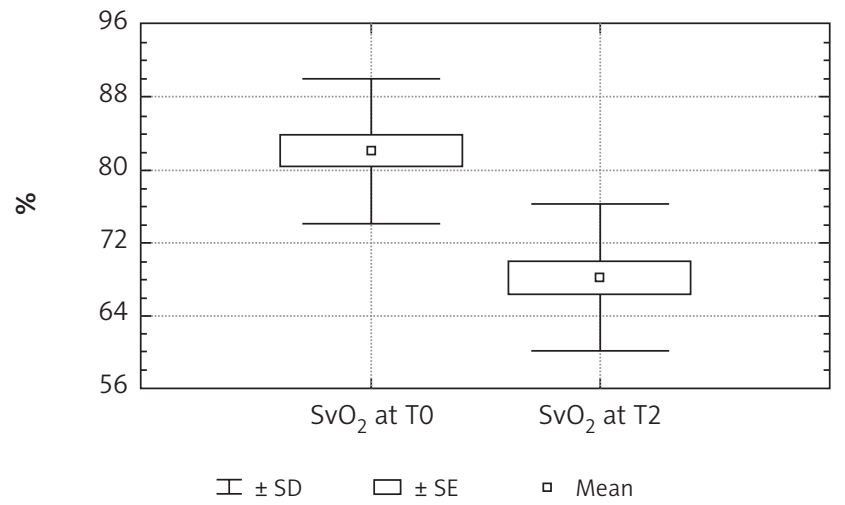

Fig. 2. Mean values of mixed venous blood saturation before and after the operation $(p<0.01)$

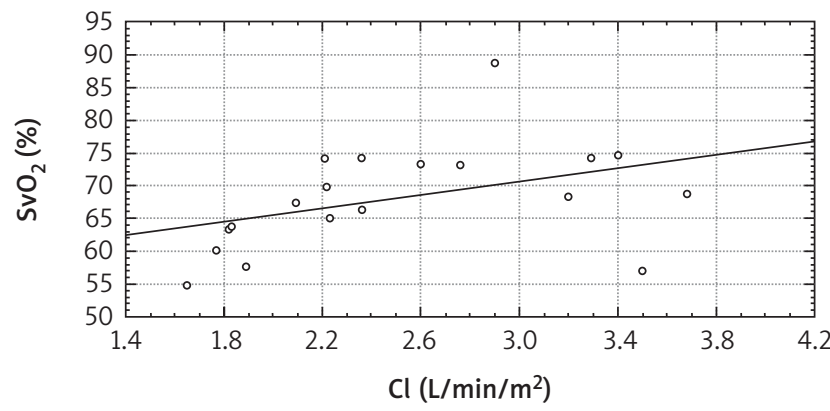

Fig. 4. Correlation between $\mathrm{Cl}$ and $\mathrm{SvO}_{2} 30$ minutes after admitting the patient to the postoperative unit $(r=0.52, p=0.02)$ 
tive result of the surgery. A gradual reduction of the dose of anesthetic drugs, restoration of homeostasis, reverse of the anticoagulant effect of heparin, the transfusion of fluids and effective analgesic therapy ultimately allow stabilization of the cardiovascular system. In some patients postoperatively the cardiac index has decreased or its value did not change. Perhaps that group of patients needed a longer period of time to achieve homeostasis, when the positive outcome of the operation showed its effect.

Many of the patients had a BMI indicating obesity (Table I). We did not analyze in the study group the liver and kidney function, adipose tissue content, serum protein concentration after cardiac operation, fluid balance type or the volume of transfusion fluids. We did not observe in every patient a return to normal values of the cardiac index after the operation. However, it was not surprising. Achieving the correct value of $\mathrm{Cl}$ in cardiac surgery patients, who have a long-term coronary heart disease or organic changes of the heart, because of, for example, coexisting valvular defects, is a process that occurs gradually and takes time [8]. The correct physiological reaction that we expected in patients after cardiac surgery was an increase of oxygen consumption by tissues. Because hemodilution used during cardiac surgery procedures impacts on the oxygen supply to the tissues, it is highly important to carry out an evaluation of the oxygen transport in patient who undergo these procedures. In patients after the operation there is an increase of the $\mathrm{VO}_{2}$ value. It can be explained by the phenomenon of the body's reflex hyperemia after ischemia, a phenomenon that is referred to in the literature as the "overshoot effect". The periodic increase of $\mathrm{VO}_{2}$ is required to compensate the oxygen debt acquired during the operation [6]. Increase of $\mathrm{VO}_{2}$ is related to the growth of the value of $\mathrm{O}_{2} \mathrm{ER}$ that we observed in our study.

When the metabolism is increased, even normal values of oxygen consumption are not sufficient to maintain the body's needs and the metabolism enters an anaerobic phase [9]. In most patients after the operation there was a decrease of mixed venous oxygen saturation, which was probably related to inadequate tissue perfusion and anaerobic metabolism of cells. This situation occurs after using cardiopulmonary bypass. After the operation the correct body compensatory response should be based on the increase of $\mathrm{Cl}$ and $\mathrm{VO}_{2}[9,10]$.

An increase of $\mathrm{VO}_{2}$ is related to a decrease of $\mathrm{SvO}_{2}$, because the oxygen uptake from blood by the tissues is associated with a decrease of $\mathrm{SvO}_{2}$ [9]. The ability to adapt to the oxygen extraction of the body's needs is one of the identifying features of a life-threatening condition; thus a reduction of $\mathrm{SvO}_{2}$ may signal a decrease of cardiac output [11]. Not every organism reacts with an increase of $\mathrm{O}_{2} E R$ to a decrease in blood flow. In some patients the oxygen concentration will stay in the range of initial values despite the changes in cardiac output, so the final value of $\mathrm{SvO}_{2}$ is not a reliable indicator of blood flow. Some of the patients in the study group responded to a decrease of $\mathrm{SvO}_{2}$ with an increase of cardiac output after the operation [12]. Per- haps the compensatory physiological response after cardiac surgery is the reason for this phenomenon. In these patients an increase of $\mathrm{Cl}$ and a decrease of $\mathrm{SvO}_{2}$ indicate an accelerated metabolism and higher oxygen demand [2, 7, 13-15]. Positive correlations between $\mathrm{SvO}_{2}$ and cardiac index before and after the operations were, respectively: $r=0.38$ (average correlation) and $r=0.52$ (high correlation). We found similar studies in the available literature where the statistical results differ from the material. Krauss et al. presented a very high correlation $(r=0.78)$ between the values of mixed venous oxygen saturation and cardiac index in patients undergoing heart or lung surgery [16]. Waller et al. when examining patients undergoing coronary artery bypass surgery, with continuous monitoring of $\mathrm{SvO}_{2}$ by SGC, found a strong correlation between changes in $\mathrm{SvO}_{2}$ and $\mathrm{Cl}$ values: $r=0.69$ [17]. The high values of $\mathrm{SvO}_{2}$ at $\mathrm{T}_{0}$ may indicate a leak caused by the change of direction of arterial blood flow (shunting) in peripheral tissues. This phenomenon occurs in states such as sepsis, and cirrhosis of the liver [18]. After excluding the possibility of existence of such diseases in patients, a probable cause of such high values of $\mathrm{SvO}_{2}$ was the admixture of oxygenated blood coming from the alveolar capillaries. To further characterize the patients after determining BMI $\left(28.02 \pm 2.8 \mathrm{~kg} / \mathrm{m}^{2}\right)$ we calculated the rate of BSA. We analyzed the BSA value, which, although it is not very specific, is however a better indicator of metabolic body weight, because it is less influenced by the excess amount of body adipose tissue. In three patients the BSA was greater than $2.0 \mathrm{~m}^{2}$, and these patients had a decrease of $\mathrm{SvO}_{2}$ and a decrease of $\mathrm{Cl}$ values after surgery.

The values of $\mathrm{BE}_{\text {ecf }}$ were below the lower reference limit, and there was a decrease of $\mathrm{DO}_{2}$. Perhaps the adipose tissue has the main impact on the value of these parameters. That phenomenon is connected with greater cardiovascular burden and the need to use higher doses of medication during the procedure and a longer return to normal body temperature [19-22].

Parameters such as $\mathrm{SaO}_{2}, \mathrm{PaO}_{2}$ and $\mathrm{PaCO}_{2}$ do not give the ability of assessing the transport of oxygen through the circulatory system.

Furthermore, the correct values of these parameters do not mean that at the subcellular level the processes involved in the extraction of oxygen proceed physiologically. Only the values of $\mathrm{SvO}_{2}$ and $\mathrm{Cl}$ obtained with the $\mathrm{SGC}$ allow the assessment of the supply of oxygen and its consumption by the tissue.

Results enriched with information such as $\mathrm{DO}_{2}, \mathrm{VO}_{2}$ and $\mathrm{O}_{2}$ ER can be very useful in treatment of patients with severe conditions, in whom the body is unable to restore homeostasis after surgery [13, 23-25].

\section{Conclusions}

1. An increase of $\mathrm{Cl}$ after the operation in comparison with $\mathrm{Cl}$ before the operation was observed.

2. In the study group there was a decrease of $\mathrm{SvO}_{2}$ after the operation in comparison with the values of $\mathrm{SvO}_{2}$ before the operation. 
3. There was a positive correlation between the trends of $\mathrm{SvO}_{2}$ and $\mathrm{Cl}$ before and after the cardiac surgery.

4. In the study group there was an increase of $\mathrm{VO}_{2}$ after the operation in comparison with the $\mathrm{VO}_{2}$ before the operation.

5. In the study group there was an increase of $\mathrm{O}_{2} \mathrm{ER}$ after the operation in comparison with $\mathrm{O}_{2} E R$ before the operation.

\section{References}

1. Rogowski J, Jarmoszewicz K, Siondalski P, Pawlaczyk R. Opieka pooperacyjna po zabiegach kardiochirurgicznych. Choroby Serca i Naczyń 2006; 3: 115-122.

2. Duarte JJ, Pontes JC, Gomes OM, Silva GV, Gardenal N, Silva AF, Viola MD. Correlation between right atrial venous blood gasometry and cardiac index in cardiac surgery postoperative period. Rev Bras Cir Cardiovasc 2010; 25: 160-165.

3. Harvey S, Young D, Brampton W, Cooper AB, Doig G, Sibbald W, Rowan K. Pulmonary artery catheters for adult patients in intensive care. Cochrane Database Syst Rev 2006; 3: CD003408.

4. Neya K. Swan-Ganz catheter (pulmonary artery catheter). Kyobu Geka 2009; 62 (8 Suppl): 677-681.

5. Aitkenhead AR, Smith G, Rowbotham DJ. Anestezjologia Polish $2^{\text {nd }}$ edition. Kübler A (ed.). Urban \& Partner, Wrocław 2008.

6. Marino PL. Intensywna terapia. Polish $1^{\text {st }}$ edition. Kübler A (ed.). Urban \&Partner, Wrocław 1991.

7. Jain A, Shroff SG, Janicki JS, Reddy HK, Weber KT. Relation between mixed venous oxygen saturation and cardiac index. Nonlinearity and normalization for oxygen uptake and hemoglobin. Chest 1991; 99: 1403-1409.

8. Wesslén O, van der Linden J, Ekroth R, Joachimsson PO, Nordgren L, Nyström SO. Myocardial recovery after cardiac surgery: a study of hemodynamic performance and electrophysiology during the first 18 postoperative hours. J Cardiothorac Anesth 1990; 4: 672-80.

9. Routsi C, Vincent JL, Bakker J, De Backer D, Lejeune P, d'Hollander A, Le Clerc JL, Kahn RJ. Relation between oxygen consumption and oxygen delivery in patients after cardiac surgery. Anesth Analg 1993; 77: 1104-1110.

10. Gerbode F, Norlander O, Herzog P, Johansson L, Osborn JJ. Oxygen uptake during anesthesia in patients before and after total body perfusion. Ann Surg 1964; 159: 481-488.
11. Andersen MN, Senning Å. Studies in oxygen consumption during extracorporeal circulation with a pump-oxygenator. Ann Surg 1958; 148: 59-65.

12. Pölönen P, Hippeläinen M, Takala R, Ruokonen E, Takala J. Relationship between intra-and postoperative oxygen transport and prolonged intensive care after cardiac surgery: a prospective study. Acta Anaesthesiol Scand 1997; 41: 810-817.

13. Videcoq $M$, Desmonts JM. What is the role of monitoring of mixed venous blood saturation in cardiac surgery? Ann Fr Anesth Reanim 1989; 8: 696-702.

14. Richard C, Thuillez C, Pezzano M, Bottineau G, Giudicelli JF, Auzepy P. Relationship between mixed venous oxygen saturation and cardiac index in patients with chronic congestive heart failure. Chest 1989; 95: 1289-1294.

15. Tulla H, Takala J, Alhava E, Huttunen $\mathrm{H}$, Kari A. Hypermetabolism after coronary artery bypass. J Thorac Cardiovasc Surg 1991; 101: 598-600.

16. Krauss XH, Verdouw PD, Hughenholtz PG, Nauta J. On-line monitoring of mixed venous oxygen saturation after cardiothoracic surgery. Thorax 1975; 30: 636-643.

17. Waller JL, Kaplan JA, Bauman DI, Craver JM. Clinical evaluation of a new fiberoptic catheter oximeter during cardiac surgery. Anesth Analg 1982; 61: 676-679.

18. Maclntyre NR, Branson RD, Wentylacja mechaniczna. Polish 1st edition. Gaszyński W (ed.). Wydawnictwo ADI, tódź 2008.

19. Francischetti EA, Genelhu VA. Obesity-hypertension - an ongoing pandemic. Int J Clin Pract 2007; 61: 269-280.

20. Molfino A, Rossi Fanelli F, Laviano A. Sympathetic nervous system activity may link hyperphagia and fat deposition in human obesity. Am J Physio Endocrinol Metab 2007; 293: E1129.

21. Collis T, Devereux RB, Roman MJ, de Simone G, Yeh J, Howard BV, Fabsitz RR, Welty TK. Relations of stroke volume and cardiac output to body composition: the strong heart study. Circulation 2001; 103: 820-825.

22. Troisi RJ, Weiss ST, Parker DR, Sparrow D, Young JB, Landsberg L. Relation of obesity and diet to sympathetic nervous system activity. Hypertension 1991; 17: 669-677.

23. Shah MR, Hasselblad V, Stevenson LW, Binanay C, O'Connor CM, Sopko G, Califf RM. Impact of the pulmonary artery catheter in critically ill patients: meta-analysis of randomized clinical trials. JAMA 2005; 294: 1664-1670.

24. Sommers MS, Stevenson JS, Hamlin RL, Ivey TD, Russell AC. Mixed venous oxygen saturation and oxygen partial pressure as predictors of cardiac index after coronary artery bypass grafting. Heart Lung 1993; 22: 112-120.

25. Bartlett R. Fizjologia stanów krytycznych. Wydawnictwo Lekarskie PZWL, Warszawa 1999 